\title{
Effects of stretching before intense exercise training on hematologic and cellular injury indices
}

\author{
Lotfi N. ${ }^{1 A B C D E}$, Mohamadi S. ${ }^{2 A B C D E}$, Mirzaei-Takmil M. ${ }^{3 A B C D E}$ \\ ${ }^{1}$ Department of Exercise physiology, Faculty of Physical Education and Sport Sciences, University of Tehran, Tehran, \\ Iran \\ ${ }^{2}$ Department of Exercise Physiology, Faculty of Physical Education and Sport Sciences, University of Kharazmi, \\ Tehran, Iran \\ ${ }^{3}$ Department of Exercise Physiology, Faculty of Physical Education and Sport Sciences, University of Guilan, Rasht, \\ Iran
}

Authors' Contribution: A - Study design; B - Data collection; C - Statistical analysis; D - Manuscript Preparation; E - Funds Collection

\begin{abstract}
Purpose: $\quad$ The aim of the study was to investigate the effect of stretching before intense exercise on hematologic parameters and cell injury.

Material: $\quad$ The subjects of the present study were 12 adolescent members of the Kurdistan Province futsal team (age: $14.83 \pm 0.38$ years, height: $173.92 \pm 5.90 \mathrm{~cm}$, weight: $63.50 \pm 7.94 \mathrm{~kg}$, peak power: $459.42 \pm 95.94$ watts). The RAST test was used to estimate the anaerobic power and to create the training load. Indexes of blood including white and red blood cells, hemoglobin, hematocrit, platelet and the levels of CK and LDH enzyme activities were measured.

Results: $\quad$ The results of the pre and the post tests showed that among hematological parameters and cell damage indexes, the red blood cell and hemoglobin in both groups and the level of LDH in the training group were not significantly changed ( $p>0.05$ ). Other parameters in the pre-test and post-test measures were statistically changed $(p<0.05)$.

Conclusions: Based on the results of the present study, it seems that stretching before intense training decreases the cell damage and side effects of exercise training on the hematological factors.

Keywords: cell damage, anaerobic exercise, muscle soreness, hematologic parameters, adolescent.
\end{abstract}

\section{Introduction}

Stretching before physical activities is considered as an important principle in all kinds of sports and is more important than the other daily activities. Stretching is recommended by scientists, physiotherapists and coaches. Flexibility is an intrinsic property of tissues that determines the achievable range of motion without injury at a joint or a group of joints [1]. In discussing the oxygen carrying capacity of blood, RBC count, hemoglobin and hematocrit are essential elements that contribute to decrease or increase in the oxygen carrying capacity of blood to the tissues and carbon dioxide desorption [2, 3]. Many studies have shown that blood factors are changed due to physical activities. Increase in blood factors have been reported in some of these studies $[4,5]$, while other studies have not reported significant changes $[6,7]$. Also in these studies there is no general consensus on the changes in blood factors. It means that some of them have reported increase and some of them have reported decrease in blood factors, while in other studies this factors have been fixed and in contrast, other factors have been changed. It is well known that stretching before exercise activities reduces musculoskeletal injury. However the effect of stretching before exercise on blood factors and intracellular injuries associated with physical activity has not been studied yet. Therefore, the aim of present study was to investigate the effects of stretching before intense physical activities on hematologic and cellular injury indices.

\footnotetext{
(c) Lotfi N., Mohamadi S., Mirzaei-Takmil M., 2018

doi:10.15561/18189172.2018.0604
}

\section{Material and methods}

Participants: 12 adolescent members of the Kurdistan Province football team (Age: $14.83 \pm 0.38$ years, height: $173.92 \pm 5.90 \mathrm{~cm}$, Weight: $63.50 \pm 7.94 \mathrm{~kg}$ and maximum power: $459.42 \pm 95.94 \mathrm{~W}$ ) participated in this study. All of them have been practicing football training programs for at latest 4 years. The study was conducted in three sessions. In the first session, individual characteristics of the subjects were recorded and the test method was illustrated. In the second session, all the participants took part in the RAST test. Then, based on the first session results, participants were divided into two groups: control group (1) and the experimental group (2). The two groups were almost identical in terms of maximal aerobic power.

\section{Testing procedures}

In the third session which was performed 72 hours after the second session, the participants were asked to stay in a rest position for 20 minutes. Then blood sampling was done from their brachial arteries. Then group 1 performed general warm up for 10 minutes before the test and the second group performed stretching exercises for 5 minutes in addition to the general warm up (for a period of 10 second per a movement). Then all the participants performed the RAST test. Blood sampling was done again after the test was conducted. The RAST test was used in order to estimate the anaerobic power and the exercise load. Two lines were identified at a distance of 35 meters from each other. Prior to the testing, subjects' weights were measured using Beurer PS06 digital. First subject 
stood behind the start line in a ready position and after hearing the command "Go" each person ran a distance of 35 meters with his maximum power and the time spent was recorded by a portable Hanhart Stopwatches made in Germany. In order to increase the accuracy and reduce the measurement error, four testers were used simultaneously and the average of three close times was considered as subject record. Then subject again started to run a distance of 35 meters with their maximum power hearing the command Go (this was measured by someone else). This was repeated for six times and it was recorded for each time. Then maximal anaerobic power of participant was calculated by the following formula [8].

$$
\begin{aligned}
& \text { Power }=\text { Weight } \times \text { Distance }^{2} \div \text { Time }^{3} \\
& \text { Power }=\text { Weight } \times 1225 \div \text { Time }^{3}
\end{aligned}
$$

To measure blood parameters, blood samples were collected in the relevant tubes and immediately were transferred to the laboratory. Then blood parameters including white blood cells (WBC), red blood cells (RBC), hemoglobin ( $\mathrm{Hgb})$, hematocrit (Hct) and platelet (Plt) were measured using cell counter machine model (Sysmex K-1000. IVB=15.20, Japan). Also enzyme activity of $\mathrm{CK}$ and $\mathrm{LDH}$ was measured using auto analyzer system (Cobas Mira Plus; Roche, Basel, Switzerland).

\section{Statistical analysis}

To describe the general characteristics of the subjects, descriptive statistics (mean and standard deviation) were used. Also, Kolmogorov-Smirnov test was used to assess data distribution, independent $t$ was used to compare two groups and dependent $t$ test was used to compare intragroup results. All the statistical tests were analyzed using SPSS Software 23 and at the significant level ( $p$ $\leq 0 / 05)$.

\section{Results}

Individual characteristics of subjects (height, age and weight) and maximum anaerobic power groups are presented in Table 1. Results of pre-test and post-test exercise and control groups (Table 2 and 3 ) showed that except for the red cell count and hemoglobin in both groups, other hematologic indices in the experimental and control groups did not change significantly $(p>0.05)$.

Also, CK enzyme has been increased significantly in both groups $(p \leq 0.05)$. But the levels of LDH showed significant increase in only the control group $(\mathrm{p} \leq 0.05)$. Also there is no difference between the changes of two groups $(\mathrm{p}>0.05)$.

Table1. Individual features and maximum anaerobic power of the two groups

\begin{tabular}{llllll}
\hline Group & $\mathbf{n}$ & Age(years) & Height $(\mathbf{c m})$ & Weight(kg) & Maximal power(W) \\
\hline Control group & 6 & $14.83 \pm 0.40$ & $173.50 \pm 6.34$ & $62.50 \pm 4.89$ & $442.33 \pm 74.49$ \\
Experimental group & 6 & $14.83 \pm 0.40$ & $174.33 \pm 5.98$ & $64.50 \pm 5.10$ & $459.42 \pm 95.94$ \\
\hline
\end{tabular}

Table 2: Comparison of pre-test and post-test in experimental group

\begin{tabular}{lllll}
\hline Variable & Pre-test & Post- test & Difference between the tests & Sig \\
\hline LDH & $379.17 \pm 51.8$ & $448.33 \pm 85.51$ & $59.16 \pm 70.19$ & 0.94 \\
CK & $370.67 \pm 123.79$ & $432.67 \pm 122.25$ & $62.00 \pm 29.11$ & $0.03^{*}$ \\
WBC & $6.8 \pm 1.33$ & $10.36 \pm 2.43$ & $3.56 \pm 1.14$ & $0.001^{*}$ \\
RBC & $5.04 \pm 0.86$ & $5.13 \pm 0.88$ & $0.11 \pm 0.14$ & $0.062^{*}$ \\
Hgb & $14.45 \pm 1.72$ & $14.73 \pm 1.7$ & $0.28 \pm 0.29$ & $0.01^{*}$ \\
Hct & $45.16 \pm 3.55$ & $48.71 \pm 2.96$ & $3.56 \pm 1.41$ & $0.002^{*}$ \\
Plt & $215.83 \pm 27.34$ & $262.17 \pm 40.51$ & $46.33 \pm 18.35$ & $0.002^{*}$ \\
\hline
\end{tabular}

*Significance between the pre-test and post-test

Table 3. Comparison of the pre-test and post-test in the control group

\begin{tabular}{lllll}
\hline Variable & Pre-test & Pre-test & Difference between the tests & Sig \\
\hline LDH & $414.33 \pm 41.03$ & $481.33 \pm 42.08$ & $67.00 \pm 39.11$ & $0.009^{*}$ \\
CK & $325.67 \pm 122.89$ & $414.5 \pm 139.87$ & $88.83 \pm 72.58$ & $0.03^{*}$ \\
WBC & $6.08 \pm 0.84$ & $9.73 \pm 1.45$ & $3.65 \pm 0.78$ & $0.00^{*}$ \\
RBC & $4.89 \pm 0.26$ & $5.03 \pm 0.23$ & $0.14 \pm 0.17$ & 0.053 \\
Hgb & $15.21 \pm 0.81$ & $15.45 \pm 0.67$ & $0.23 \pm 0.46$ & $0.012^{*}$ \\
Hct & $44.91 \pm 1.76$ & $48.76 \pm 2.25$ & $3.85 \pm 2.03$ & $0.006^{*}$ \\
Plt & $214.17 \pm 33.91$ & $247.67 \pm 52.27$ & $60.50 \pm 21.19$ & $0.001^{*}$ \\
\hline
\end{tabular}

*Significance between the pre-test and post-test 


\section{Discussion}

The present study has tried to examine the effect of stretching before exercise on some of the cell injury and hematological indexes. Lactate dehydrogenase enzyme (LDH) exists in different tissues of body and its concentration is high in liver, kidney, skeletal muscle and other tissues. When the muscle cell is injured due to physical activity, LDH concentration is increased [9]. Muscle cell membrane permeability is increased due to muscle activity or maybe the muscle cell is completely ruptured. Therefore, the relevant enzymes enter the blood circulation [10]. Based on the results, it seems that stretching before intense exercise may reduce the probability of cell injury associated with the physical activity. Significant increase in LDH enzyme level in the control group is consistent with Ferri et al (2006) [11].

Also, the results showed that in both groups, CK enzyme increased significantly. However, the increase was lower in the experimental group compared to control group. Measuring CK level in the blood, is another criterion to measure muscle injury $[12,13]$. Normally, CK can be seen in the muscles, but when the muscles are injured, it enters the blood circulation .After exercise, those athletes who have more CK in their circulation, experience greater muscle pain $[9,12]$. According to the results of the present study, although, changes in CK levels in both groups was significant, but experimental group showed less changes compared to the control group. So, it seems that stretching before severe exercise reduces cell injury.

The results showed that white blood cell count (WBC) has been increased significantly in both the experimental and control groups. However, the increase in white blood count in experimental group was lower than that of the control group. Different studies have shown that white blood cells increase significantly after exercise and this is called leukocytosis [14]. Leukocytosis is one of the clear changes appear after severe or moderate physical activities and white blood cell level remain high for several hours during these activities [3]. The results are consistent with the study by Simonson et al (2001) and Anseli et al $(2007)[6,7]$. In contrast, the study is not consistent with that of Arazi et al (2011) in which they reported no significant increase in white blood cell levels [3]. Since, leukocytosis level is directly related to the severity of the exercise; it seems that this disagreement is related to the exercise protocol. Although, no significant difference has been found in both groups, but because white blood cell increase was lower in experimental group compared to the control group, it seems that stretching before intense physical activity reduces the stress on immune system and in turn reduces immune system reaction to the stress.

The results of the study showed that red blood cells count and hemoglobin level have not changed significantly in both experimental and control groups. Two possible mechanisms have been discussed in different studies on the changes in red blood cell count. First, some studies have shown that blood factors are reduced during intense physical activities (Hemoglobinuria). Second, other studies have reported that during exercise, due to the released stored erythrocytes from spleen, erythrocytes and hemoglobin are increased in the blood [18-20]. This study shows that changes in hemoglobin and erythrocytes may depend on equivalency between the two mechanisms. Schumacher et al (2002) and Choudhary et al (2011) reported that hemoglobin level remains close to the standard level in people who have exercised and increase in the release of erythrocytes from spleen may be seen in those subjects who have not exercised [21, 22]. Since the subjects of present study were athletes, our result is in agreement with this study and this accounts for the disagreement with results of the present study and those of Arazi et al (2011), Brown et al (2002) and Nazarali et al (2012) who have reported increase in the level of erythrocytes and hemoglobin [3, 23, 24].

The results of our study show that hematocrit have increased significantly in both experimental and control groups. Since hematocrit is defined as the amount of RBC in certain volume of blood, on the one hand, it is related to $\mathrm{RBC}$ volume and on the other hand, it is related to plasma volume [3, 17]. Therefore, given that the number of RBC and hemoglobin didn't change significantly in this study, the observed increase in hematocrit will be due to decrease in plasma volume. It has been reported that during intense exercise temporarily plasma volume decreases by as much as 6 to 20 percent $[25,26]$. Three mechanisms are assumed to account for initial decrease in plasma volume: first, increase in arterial blood pressure and muscle contraction increased capillary hydrostatic pressure. This drives the fluid into the extravascular space. Second, lactic acid and other metabolites produced by contraction of muscles during intense exercising drives blood fluid into the extravascular space (osmosis). Finally, increase in intangible excretion and sweating is influenced by net decrease in intravascular plasma volume in critical conditions 27, 28]. This factor reduces plasma volume and in turn increases hematocrit.

Also this study indicates that platelet levels have been increased significantly in both the control and the experimental groups. Increase of the platelet number was due to the release of new platelet from the spleen vascular bed, marrow and other platelet storage in the body [3]. The exercise protocol used in this study leads to increase of platelet production (thrombotic factor) because it causes small possible injuries. However, Siscovick et al reported that initial cardiac arrest risk will be increased temporarily during physical activity. Therefore, it appears that on the one hand, physical activity prevents from cardiovascular disease and on the other hand it leads to sudden cardiac death [29]. This may leads to thrombosis in coronary circulation and increases the risk of cardiac arrest [30]. The results of the present study show that number of platelet have been increased significantly in both control and experimental groups. This increase was lower in the experimental group that had performed stretching exercises. Therefore, it seems that stretching before intense exercises reduces platelet changes and its effects. 


\section{Conclusions}

Based on the results of present study, it appears that stretching before intense physical activities decreases cell injury and its adverse effects on blood factors. However, it is suggested that further studies investigate the effect of stretching on other factors including anaerobic exercises.

\section{References}

1. Gremion G. The effect of stretching on sports performance and the risk of sports injury: A review of the literature. Schweiz Z Med Traumatol. 2005;53(1):6-10.

2. Gaeini AA, compare the effect of maximal and sub-maximal exercises on hematological parameters in athletic and nonathletic young male students, Journal of Harkat. 2000; 3: 53-64.

3. Arazi H., Damirchi A, Mostafaloo A. Variation of hematological parameters following repeated bouts of concurrent endurance-resistance exercises, journal of Jahrom University Medical Sciences. 2011, 9 (2): 48-54. (In Persian).

4. Field CJ, Gougeon R, Marliss EB. Circulating mononuclear cell numbers and function during intense exercise and recovery. J Appl Physiol. 1991;71(3): 1089-97. https://doi.org/10.1152/jappl.1991.71.3.1089

5. Nielsen HB, Secher NH, Christensen NJ, Pedersen BK. Lymphocytes and NK cell activity during repeated bouts of maximal exercise. Am J Physiol. 1996;271(1):R222-R7.

6. Robson-Ansley PJ, Blannin A, Gleeson M. Elevated plasma interleukin-6 levels in trained male triathletes following an acute period of intense interval training. Eur J Appl Physiol. 2007;99(4): 353-60. https://doi.org/10.1007/s00421-006-0354-y

7. Simonson SR. The immune response to resistance exercise. $J$ Strength Cond Res. 2001;15(3):378-84.

8. Arazi H, Lotfi N, Rostamkhani H. The effects of acute inhaled Salbutamol on power output and blood lactate concentration in non-asthmatic elite kung fu athletes. Sci Mov Health Romania. 2011;11(2):175-9.

9. Amirsasan, R., Nikookheslat, S., Sari-Saraf, V., Batoorak K., Letafatkar, A., The effect of two dosage of BCAA supplementation on wrestlers' serum indexes on cellular injury. Journal of Research in Medical Sciences. 2012; 13(8): 22-28.

10.Greer BK, Woodard JL, White JP, Arguello EM, Haymes EM. Branched-chain amino acid supplementation and indicators of muscle damage after endurance exercise. Int J Sport Nutr Exerc Metab. 2007;17(6): 595-607. https://doi.org/10.1123/ijsnem.17.6.595

11.Ferri A, Narici M, Grassi B, Pousson M. Neuromuscular recovery after a strength training session in elderly people. Eur $J$ Appl Physiol. 2006;97(3): 272-9. https://doi.org/10.1007/s00421-006-0168-y

12.Howatson G, Hoad M, Goodall S, Tallent J, Bell $\mathrm{PG}$, French DN. Exercise-induced muscle damage is reduced in resistance-trained males by branched chain amino acids: a randomized, double-blind, placebo controlled study. J Int Soc Sports Nutr. 2012;9(1): 20. https://doi.org/10.1186/1550-2783-9-20

13.Mackey AL, Brandstetter S, Schjerling P, Bojsen-Moller J, Qvortrup K, Pedersen MM, et al. Sequenced response of extracellular matrix deadhesion and fibrotic regulators after muscle damage is involved in protection against future injury in human skeletal muscle. FASEB J. 2011;25(6): 1943-59. https://doi.org/10.1096/fj.10-176487

14.Risøy BA, Raastad $\mathrm{T}$, Hallén J, Lappegård KT,

\section{Acknowledgement}

I would like to appreciate all who have helped us in this study especially, the head of Razi Laboratory, Mr. Behruz Mohseni and the laboratory staff.

\section{Conflict of interests}

The authors declare that there is no conflict of interest.

Bæverfjord K, Kravdal A, et al. Delayed leukocytosis after hard strength and endurance exercise: Aspects of regulatory mechanisms. BMC physiol. 2003;3(1): 14. https://doi.org/10.1186/1472-6793-3-14

15.Nieman D, Simandle S, Henson D, Warren B, Suttles J, Davis $\mathrm{J}$, et al. Lymphocyte proliferative response to 2.5 hours of running. Int J Sports Med. 1995;16(06): 404-9. https://doi.org/10.1055/s-2007-973028

16.Villa G, Aguiló A, Tur J, Pons A. Hand strike-induced hemolysis and adaptations in iron metabolism in Basque ball players. Ann Nutr Metab. 2006;50(3): 206-13. https://doi.org/10.1159/000090742

17.Yalcin O, Erman A, Muratli S, Bor-Kucukatay M, Baskurt OK. Time course of hemorheological alterations after heavy anaerobic exercise in untrained human subjects. J Appl Physiol. 2003;94(3): 997-1002. https://doi.org/10.1152/japplphysiol.00368.2002

18.Gaudard A, Varlet-Marie E, Bressolle F, Mercier J, Brun J-F. Hemorheological correlates of fitness and unfitness in athletes: Moving beyond the apparent "paradox of hematocrit"? Clin Hemorheol Microcirc. 2003;28(3):161-73.

19. Senturk UK, Yalcin O, Gunduz F, Kuru O, Meiselman HJ, Baskurt OK. Effect of antioxidant vitamin treatment on the time course of hematological and hemorheological alterations after an exhausting exercise episode in human subjects. $J$ Appl Physiol. 2005;98(4): 1272-9. https://doi.org/10.1152/japplphysiol.00875.2004

20.Wilmore JH, Costill DL, Kenney WL. Physiology of sport and exercise: Human kinetics USA; 2004.

21.Choudhary S, Binawara BK. Effect of exercise on serum iron, blood haemoglobin and cardiac efficiency. J Postgraduate Medic Ins. 2011;26(1)

22.Schumacher YO, Schmid A, Grathwohl D, Bultermann D, Berg A. Hematological indices and iron status in athletes of various sports and performances. Med Sci Sports Exer. 2002;34(5): 869-75. https://doi.org/10.1097/00005768-200205000-00022

23.Brun JF, Connes P, Varlet-Marie E. Alterations of blood rheology during and after exercise are both consequences and modifiers of body's adaptation to muscular activity. Sci Sports. 2007;22(6): 251-66. https://doi.org/10.1016/j.scispo.2007.09.010

24.Nazarali P., Sarvari S., Ramezankhani, A., The Effect of Maximal Endurance Training on Hemorheological Factors of National Athletes of Triathlon. Journal of Sports Sciences. 2012, 15 (4): 63-75

25.Van Rensburg J, Kielblock A, Van der Linde A. Physiologic and biochemical changes during a triathlon competition. Int $J$ Sports Med. 1986;7(01): 30-5. https://doi.org/10.1055/s-2008-1025731

26.Davidson R, Robertson J, Galea G, Maughan R. Hematological changes associated with marathon running. Int $J$ Sports Med. 1987; 8(01): 19-25. https://doi.org/10.1055/s-2008-1025634

27.Eichner ER. Sports anemia, iron supplements, and blood doping. Med Sci Sports Exer. 1992;24(9): S315-S8. https://doi.org/10.1249/00005768-199209001-00002 
28.Selby GB, Eichner ER. Hematocrit and performance: the effect of endurance training on blood volume. Semin Hematol. 1994; 31(2):122-7.

29.Siscovick DS, Weiss NS, Fletcher RH, Lasky T. The incidence of primary cardiac arrest during vigorous exercise. New Engl J Med. 1984;311(14): 874-7. https://doi.org/10.1056/NEJM198410043111402
30.Wang G-J, Volkow ND, Fowler JS, Franceschi D, Logan J, Pappas NR, et. al. PET Studies of the effects of aerobic exercise on human striatal dopamine release. $J$ Nucl Med. 2000;41(8):1352-6.

\section{Information about the authors:}

Lotfi N. (Corresponding author); PhD in Exercise Physiology; http://orcid.org/0000-0002-1366-5058; navid_lotfi2008@yahoo.com; Department of Exercise physiology, Faculty of Physical Education and Sport Sciences, University of Tehran; 15 th St., North Karegar St., Tehran, Iran. P.O.Box: 14398-13117, Iran.

Mohamadi S.; Ph.D. student of Exercise Physiology; http://orcid.org/0000-0002-3603-8161; S.Mohamadi2000@yahoo.com; Department of Exercise Physiology, Faculty of Physical Education and Sport Sciences, University of Kharazmi; Tehran, No.43.South Mofatteh Ave. Postal code: 14911 - 15719, Iran.

Mirzaei-Takmil M.; Ph.D. student of Exercise Physiology; http://orcid.org/0000-0002-3937-4128; maryam.mirzaei307@gmail.com; Department of Exercise Physiology, Faculty of Physical Education and Sport Sciences, University of Guilan; Rasht, Khalij Fars highway, 5th kilometer of Ghazvin road, 4199613776, Iran.

Cite this article as: Lotfi N, Mohamadi S, Mirzaei-Takmil M. Effects of stretching before intense exercise training on hematologic and cellular injury indices. Pedagogics, psychology, medical-biological problems of physical training and sports, 2018;22(6):301305. https://doi.org/10.15561/18189172.2018.0604

The electronic version of this article is the complete one and can be found online at: http://www.sportpedagogy.org.ua/index.php/PPS/issue/archive

This is an Open Access article distributed under the terms of the Creative Commons Attribution License, which permits unrestricted use, distribution, and reproduction in any medium, provided the original work is properly cited (http://creativecommons.org/licenses/by/4.0/deed.en).

Received: 01.08.2018

Accepted: 10.09.2018; Published: 22.12.2018 